\title{
Metode Pembelajaran Discovery dalam Mengembangkan Proses Berfikir Kreatif Anak
}

\author{
Zahrina Amelia ${ }^{1}$, Nila Fitria ${ }^{2}$ \\ Program studi Pendidikan Guru Pendidikan Anak Usia Dini, Fakultas Psikologi dan Pendidikan, \\ Universitas Al Azhar Indonesia, Jalan Sisingamangaraja, Kompleks Masjid Agung Al Azhar, Kebayoran baru, \\ Jakarta Selatan 12110
}

Penulis untuk Korespondensi/E-mail: zahrina.amelia@uai.ac.id

\begin{abstract}
Abstrak - Penelitian ini bertujuan untuk mendapatkan gambaran pola dan data empiris mengenai metode pembelajaran discovery dalam mengembangkan proses berpikir kreatif anak usia 6-7 tahun di wilayah Jakarta selatan. Penelitian ini menggunakan metode kualitatif dan dilaksanakan pada orang tua dan anak usia 6-7 tahun di Wilayah Jakarta Selatan. Prosedur pengumpulan data dilakukan dengan cara observasi, wawancara dan dokumentasi. Anaklisis data memnggunakan reduksi data, display data dan verivikasi/ kesimpulan. Pemeriksaan data dilakukan dengan triangulasi data dan member check. Temuan hasil penelitian menunjukkan metode pembelajaran discovery dalam mengembangkan proses berpikir kreatif anak yaitu: (1) anak bertanya dan mengeksplorasi lingkungan sekitar pada saat mengumpulkan informasi. (2) anak berbincang-bincang untuk bertukar informasi yang dimiliki. (3) anak menyampaikan dan menguji ide yang dimilikinya. (4) anak mengidentifikasi ide yang yang dimilikinya telah sempurna atau membutuhkan penyempurnaan. Hal tersebut juga didukung oleh guru dengan menyajikan masalah, membimbing dan mengawasi anak untuk bereksplorasi dan menemukan jawabannya. Implikasi dari penelitian ini adalah secara teoritis, proses berpikir kreatif dapat dilakukan di setiap sekolah melalui kegiatan yang memberikan ruang untuk anak menemukan idea tau jawabannya sendiri. Secara praktis proses berpikir kreatif akan berkembang dengan baik apabila terdapat dukungan dari guru dan lingkungan anak. Guru dapat menciptakan lingkungan yang kondusif dan lingkungan yang mendukung anak untuk menemukan ide-ide baru.
\end{abstract}

Abstract - This study aims to obtain an overview of patterns and empirical data regarding discovery learning methods in developing creative thinking processes for children aged 6-7 years in the South Jakarta area. This research used qualitative methods and was carried out on parents and children aged 6-7 years in the Jakarta Selatan area. The data collection procedure was carried out through observation, interview, and documentation. Data analysis using data reduction, data display, and verification/conclusion. Data checking was performed by data triangulation and member checks. The findings of the research show that discovery learning methods in developing children's creative thinking processes are: (1) children ask questions and explore their surroundings when collecting information. (2) children chat to exchange information they have. (3) children convey and test the ideas they have. (4) children identify ideas that they have are perfect or need refinement. This is also supported by the teacher by presenting problems, guiding, and supervising children to explore and find answers. This research implies that theoretically, the creative thinking process can be carried out in every school through activities that provide space for children to find their ideas or answers. Practically, the creative thinking process will develop well if there is support from the teacher and the child's environment. The teacher can create a conducive environment and an environment that supports children to find new ideas.

Keywords - creativity, acquisition creative thinking process, discovery learning methods 


\section{PENDAHULUAN}

$\mathrm{M}$ asa usia dini merupakan masa yang terpenting untuk mengembangkan berbagai kemampuan yang akan menjadi modal untuk anak bersaing di era globalisasi ini. Berbagai kemampuan anak salah satunya dapat dikembangkan melalui metode pembelajaran STEM adalah akronim dari science, technology, engineering, dan mathematics. Kata STEM diluncurkan oleh National Science Foundation AS pada tahun 1990-an sebagai sebagai tema gerakan reformasi pendidikan dalam keempat bidang disiplin tersebut untuk menumbuhkan angkatan kerja bidang-bidang STEM, serta mengembangkan warga negara yang melek STEM, serta meningkatan daya saing global AS dalam inovasi iptek [1]. Tujuan pengajaran dalam pendidikan STEM meliputi pengembangan pengetahuan konten dan pengembangan kemampuan ilmiah umum. Salah satu kemampuan ilmiah umum tersebut adalah penalaran ilmiah yang berhubungan dengan kemampuan kognitif seperti pemikiran kritis dan penalaran. Salah satu yang dapat dipelajari dari STEM yaitu metode pembelajaran discovery.

Terdapat berbagai metode pembelajaran salah satunya metode pembelajaran discovery.menurut Hamalik menyatakan bahwa discovery adalah proses pembelajaran yang menitikberat kan pada mental intelektual pada anak didik dalam memecahkan berbagai persoalan yang dihadapi [2], sehingga menemukan suatu konsep yang dapat diterapkan di lapangan. Proses pembelajaran tersebut dapat di kait kan dengan kegiatan pembelajaran sains untuk anak. Pada kegiatan tersebut anak dapat menggali rasa ingin tahunya (bereksplorasi). Kegiatan sains tersebut juga dapat mengembangkan kemampuan anak. Pada kenyataanya kegiatan pembelajaran lebih mementingkan agar anak dapat menulis, berhitung dan membaca dengan baik. Bukhari menjelaskan bahwa "berdasarkan pengamatan di sejumlah TK, selain diajarkan bernyanyi dan keterampilan untuk melatih motoric, setiap harinya murid-murid TK juga mendapat pendidikan mengenal huruf-huruf alphabet serta angka. Bahkan anak-anak yang masih berusia 4-5 tahun juga diharuskan berlatih menuliskannya dalam buku tulis seperti halnya murid sekolah dasar".

Hal itu selain melanggar aturan, juga dikhawatirkan akan berpengaruh negatif pada perkembangan anak. Hal ini dikarenakan pada usia ini anak sebaiknya diberikan metode pembelajran yang dapat membantu anak mengeksplorasi dan belajar memecahkan masalah yang ada sekitarnya.

Pada saat bermain anak akan merasakan kenyamanan dan kesenangan. Menurut Tedjasaputra bermain adalah "Pada saat bermain anak secara tidak sadar akan mendapat pengetahuan baru dari eksplorasinya terhadap lingkungan [3]. Hal tersebut ditunjang dengan studi George Land dalam Break Point and Beyond menunjukkan fakta bahwa, anak yang berusia 5 tahun mencetak skor kreativitas sebanyak $98 \%$, anak usia 10 tahun $32 \%$, remaja berusia 15 tahun $10 \%$, dan orang dewasa $2 \%$. Studi tersebut memperlihat kan bahwa pada anak usia taman kanak-kanak khususnya sangat berkembang kreativitasnya. Namun hal itu bergantung pada metode pembelajaran yang berikan disekolahnya.

Tujuan dari penelitian ini adalah mendapat gambaran mengenai metode pembelajaran discovery dalam mengembangkan proses berpikir kreatif anak. Adapun manfaat dari penelitian ini, secara praktis, adalah memberikan informasi yang dapat membantu pengajar dan orang tua dalam memberikan kegiatan yang bermakna bagi anak.

\section{METODE}

Penelitian ini dilakukan dengan metode kualitatif, karena peneliti ingin mendapat gambaran yang jelas dan akurat mengenai materi atau fenimena yang diselidiki secara ilmiah. Sukmadinata mengatakan bahwa, "Penelitian kualitatif (Qualitatif research) adalah suatu penelitian yang ditunjukkan untuk mendeskripsikan dan menganalisis fenomena, peristiwa, aktivitas sosial, sikap, kepercayaan, pesepsi, pemikiran orang secara individual maupun kelompok" [4]. Dengan demikian dalam penelitian kualitatif peneliti akan menggambarkan dan menganalisa aktivitas yang dilakukan subjek penelitian baik secara individual

Berdasarkan penjelasan diatas penelitian ini dilakukan untuk mengambarkan dan melaporkan metode pembelajaran discovery dalam mengembangkan proses berfikir kreatif anak yang meliputi tahapan persiapan,berdiskusi, menemukan ide atau menjawab dan mengaplikasikannya di TK Green School Permata Assolihin. 


\section{Latar Penelitian}

\section{Tempat Penelitian}

Penelitian berlokasi pada TK GSPA di daerah petukangan selatan kelurahan pesanggrahan. TK GSPA merupakan salah satu TK yang kegiatan pembelajarannya lebih banyak di alam terbuka. TK GSPA tidak menggunakan kelas yang pada umumnya, melainkan kelas- kelas dibuat seperti saung terbuka dan memiliki sirkulasi udara yang besar.

TK GSPA memiliki lapangan yang cukup luas untuk menunjang kegiatan belajar yang dilakukan oleh siswa untuk kegiatan bermain bebas diluar ruangan. Lalu juga mempunyai rumah pohon yang di design bertingkat. TK Green School Permata Assholihin juga mempunyai rumah kayu yang sederhana, anakanak biasa menyebutnya "Rumah Pelangi" karena rumah kayu tersebut diberi wana-warni menyerupai warna pelangi.

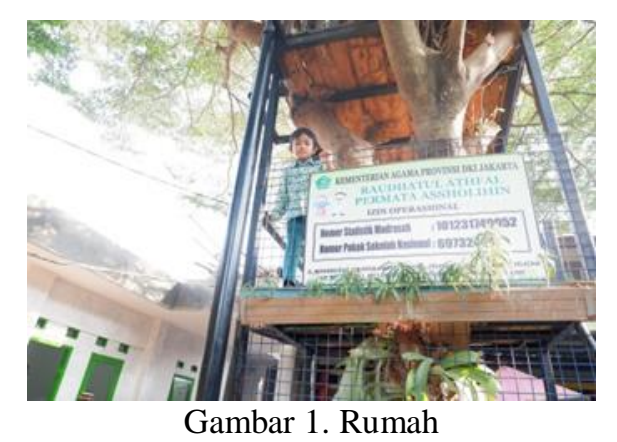

\section{Waktu Penelitian}

Peneliti melaksanakan penelitian dari pengajuan judul hingga pelaporan selama tujuh bulan yaitu dari proses persiapan sampai dengan penyerahan laporan akhir. Berikut merupakan Tabel 1 rangkaian pelaksanaan kegiatan;

Tabel 1. Waktu Penelitian

\begin{tabular}{|c|c|c|c|c|c|c|c|}
\hline \multirow[t]{2}{*}{ No } & \multirow[t]{2}{*}{ Kegiatan } & \multicolumn{6}{|c|}{ Bulan Ke- } \\
\hline & & 1 & 23 & $\begin{array}{ll}34 \\
\end{array}$ & 45 & 6 & 7 \\
\hline 1 & $\begin{array}{l}\text { Persiapan } \\
\text { (responden,pandu } \\
\text { an observasi dan } \\
\text { wawancara) }\end{array}$ & $\mathbf{X}$ & $\mathbf{X}$ & & & & \\
\hline 2 & Pengambilan data & & $\mathbf{X} X$ & $\mathbf{X} \mathbf{X}$ & $\mathbf{X}$ & & \\
\hline 3 & Analisis data & & & $\mathbf{X}$ & $\mathbf{X} X$ & & \\
\hline 4 & $\begin{array}{l}\text { Pembuatan } \\
\text { laporan }\end{array}$ & & & & & $\mathbf{x}$ & $\mathbf{X}$ \\
\hline 5 & $\begin{array}{ll}\text { Seminar } & \text { Hasil } \\
\text { Penelitian } & \\
\end{array}$ & & & & & & $\mathbf{X}$ \\
\hline
\end{tabular}

\begin{tabular}{|c|c|c|c|c|c|c|c|}
\hline \multirow[t]{2}{*}{ No } & \multirow[t]{2}{*}{ Kegiatan } & \multicolumn{6}{|c|}{ Bulan Ke- } \\
\hline & & 12 & 23 & 4 & 5 & 6 & 7 \\
\hline 6 & $\begin{array}{l}\text { Penggandaan, } \\
\text { pengiriman, dan } \\
\text { penyerahan } \\
\text { laporan akhir }\end{array}$ & & & & & & $\mathbf{X}$ \\
\hline
\end{tabular}

\section{Prosedur Penelitian}

Teknik pengumpulan data pada penelitian kualitatif berbeda dengan penelitian kuantitatif. Sugiyono mengatakan bahwa peneliti kualitatif disebut sebagai human instrumen [5]. Peneliti berfungsi untuk menetapkan fokus penelitian, memilih informan sebagai sumber data, melakukan pengumpulan data, menilai kualitas data, menganalisis data, menafsirkan dan membuat kesimpulan atas temuannya. Sumber data diperoleh dari informan di TK Green School Permata Assolihin.

1. Observasi

Observasi yang di lakukan adalah dalam penelitian menurut Faisa dalam Sugiyono diklasifikasikan menjadi 3 jenis yaitu, "Observasi berpartisipasi (participant observation), observasi secara terang -terangan dan tersamar (overt observation and convert observation), dan observasi tidak terstruktur (unstructured observation)." [5]. Pada observasi partisipatif, peneliti mengamati tindakan, mengedengarkan ucapan dam berpartisipasi pada kegiatan yang dilakukan. Observasi berpartisipasi dilakukan agar dapat menjalin hubungan antara peneliti dan narasumber selama penelitian berlangsung. Obeservasi ini dilakukan dengan melihat metode pembelajaran discovery dalam mengembangkan proses berpikir kreatif anak. Hasil pengamatan diberi kodel CL (catatan lapangan)

2. Wawancara

Pada penelitian kualitatif peneliti memerlukan wawancara untuk menunjang teknik data lainnya. Moleong mengatakan, wawancara adalah percakapan dengan maksud tertentu yang dilakukan oleh dua belah pihak [6]. Pecakapan dilakukan oleh dua belah pihak, yaitu pewawancara (interviewer) sebagai yang mengajukan pertanyaan dan terwawancara (interviewe) yang memberikan jawaban atas pertanyaan Hasil wawancara akan disimpan dalam bentuk tulisan dengan kode CW (Catatan Wawancara). 
3. Dokumentasi

Studi dokumentasi dilakukan untuk melengkapi data yang diperoleh melalui pengamatan dan wawancara. Dokumentasi dilakukan untuk memberikan bukti atas kegiatan yang dilakukan. Imam mengatakan bahwa studi dokumentasi disebut juga dengan jenis pengumpulan data audio visual [7]. Audio visual dapat berupa foto atau kaset video. Oleh karena itu, peneliti menggunakan studi dokumentasi untuk mendukung hasil penelitian. Melalui dokumentasi yang dikumpulkan dapat dijadikan sumber data yang digunakan sebagai bahan analisa. Hasil dokumentasi akan disimpan dalam bentuk tulisan, gambar/foto dengan kode CD (Catatan Dokumentasi).

\section{Analisis Data}

Teknik analisis data yang digunakan dalam peneltian ini adalah metode Miles and Huberman, mengemukakan bahwa terdapat empat aktivitas yang dilakukan dalam analisis data [8]. Aktifitas yang dilakukan dalam analisis data yaitu. Langkahlangkah analisis dijabarkan pada Gambar.1;

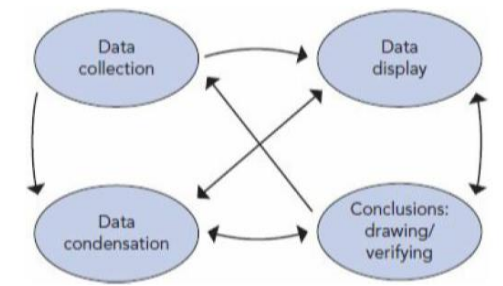

Gambar 1. Langkah analisis data menggunakan metide Miles and Huberman.

Berdasarkan gambar tersebut terlihat bahwa setelah peneliti melakukan pengumpulan data, maka peneliti melakukan antisipasi sebelum melakukan reduksi data. Miles and Huberman menjabarkan langkah-langkah menganalisis data, antara lain: (1) data reduction, (2) data display, dan (3) conclution drawing/ verification.(4) Pemeriksaan dan keabsahan Data (perpanjangan pengamatan, triangulasi dan member check

\section{HASIL DAN PEMBAHASAN}

\section{Deskripsi Data}

\section{Gambaran Umum TK GSPA}

TK GSPA merupakan salah satu sekolah dengan metode sentra yang berada di Jakarta Selatan. TK GSPA tidak hanya berfokus pada penyelenggaraan pendidikan TK saja, akan tetapi kini meranah dipendidikan SD berbasis sentra yang mana kini sedang tahap pengembangan. TK GSPA berfokus untuk menciptakan lingkungan yang kondusif, islami, aman dan nyaman. Melaksanakan pendekatan pembelajaran kreatif, inofatif, menyenangkan dan mengembangkan kecerdasan jamak (Multiple Intellegence). Melaksanakan norma-norma agama menjadi pembiasaan seharihari. Melaksanakan pembelajaran yang memahami ilmu pengetahuan dan teknologi. Melaksanakan pembelajaran berbasis life skill dan kewirausahaan. Mengupayakan tersedianya sarana dan prasarana yang memadai. Mengintergrasikan nilai-nilai budaya kedalam kegiatan pembelajaran. Menanamkan akhlaqul karimah sejak usia dini. Menanamkan nilai-nilai kebangsaan (keberanian, kepahlawanan, cinta tanah air dalam kegiatan pembelajaran).

Hal tersebut telihat bahwa TK GSPA memiliki karakteristik didalam program kemampuan dasar islam dalam pembiasaan sehari-hari. Kurikulum yang digunakan TK Green School Permata Assholihin mengacu pada kurikurum 2013 dan menjadikan alam sebagai media belajar.

\section{Analisis Data \\ Proses Anak Usia Dini Mengumpulkan Informasi untuk Menjawab atau Memecahkan Masalah Pada Pembelaaran Discovery anak merasa puas terhadap ide yang ia miliki atau jika butuh penyempurnaan guru akan membantunya untuk hasil yang baik.}

\section{Temuan Penelitian}

Berdasarkan hasil analisis data di atas melalui reduksi data, display data dan verifikasi data diperoleh beberapa temuan teoritis yang berkaitan dengan modek pembelajaran discovery dalam pemerolehan proses berpikir kreatif, yaitu:

1. Proses berpikir kreatif mulai muncul pada anak usia dini melalui kegiatan tanya jawab dan eksplorasi terhadap lingkungan sekitar.

2. Proses berpikir kreatif d itunjukkan anak usia dini melalui perilaku berbincang-bincang dengan orang lain. Perilaku tersebut dilakuka telah anak selesai bertanya dan berksplorasi terhadap lingkungan sekitarnya.

3. Proses berpikir kreatif juga ditunjukkan anak usia dini pada saat anak menyampaikan ide dan menguji ide yang dimilikinya.

4. Proses berpikir kreatif anak usia dini tidak berhenti sampai anak menguji atau melaksanakan nya, tetapi anak mencoba mengidentifikasi ide yang dimilikinya telah 
sempurna atau membutuhkan penyempurnaan melalui kegiatan evaluasi.

Berdasarkan penjabaran di atas dapat di deskripsikan bahwa karakteristik berpikir kreatif anak dalam dilakukan melalui kegiatan yang di seleggarakan sekolah melalui metode pembelajaran discovery yatu: anak bertanya dan bereksplorasi, anak berbincang-bincang dengan orang lain, anak menjelaskan apa yang ingin dilakukan, dan menjelaskan dan pada akhir kegiatan anak mengevaluasi. Masing masing temuan tersebut dapat dijabarkan sebagai berikut;

TK Permata Assolihin lebih banyak memberikan kegiatan-kegiatan yang mengajak anak untuk mengeksplorasi lingkungan sekitar dan mengembangkan proses berpikir kreatifnya. Anak akan membangun proses berpikir kreatif ketika guru memberikan kegiatan disetiap harinya. Kegiatan dimulai dari guru menjelaskan tema dan memberikan kegiatan atau masalah. Kemudian guru memberikan kesempatan anak untuk bereksplorasi dan menemukan jawabannya. Pada metode pembelajaran discovery guru berperan menyiapkan, membimbing, dan mengawasi anak untuk memecahkan atau melaksanakan kegiatan tersebut.

\section{Pembahasan Temuan Penelitian}

Berdasarkan hasil analisis data melalui reduksi data, display dan verifikasi data diperoleh beberapa hal yang berkaitan dengan metode pembelajaran discovery dalam mengembangkan proses berpikir kreatif anak. Sekolah tersebut setiap harinya melakukan kegiatan yang mengajak anak untuk menggali pengetahuannya secara langsung. Kegiatan yang dilakukan akan membimbing anak untuk mengeksplorasi lingkungan sekitar dan mendapat pengetahuan baru. Hal tersebut senada dengan pendapat Hosnan yaitu, discovery learning adalah suatu metode untuk mengembangkan cara belajar aktif dengan menemukan sendiri, menyelidiki sendiri, maka hasil yang diperoleh akan setia dan tahan lama dalam ingatan [9]. Melalui belajar penemuan, siswa juga bisa belajar berpikir analisis dan mencoba memecahkan sendiri masalah yang dihadapi. Pada metode pembelajaran ini anak akan belajar melalui pelibatan diri yang total, guru hanya sebagai fasilitator dan pengawas pada saat kegiatan berlangsung.

Setiap kegiatan yang dilakukan guru selalui memulai dengan mengenalkan tema, nama kegiatan dan menjelaskan kegiatan yang akan dilakukan. Setelah itu anak akan mengumpulkan informasi yang dilakukan untuk membantu menemukan jawaban. Anak mengumpulkan informasi dengan cara bertanya dengan mengeksplorasi dengan lingkungan sekitar. Sesuai dengan Veerman dalam Kurniasih langkah-langkah dalam metode pembelajaran discovery antara lain (1) orientation (guru memberikan kegiatan dari tema/ materi yang diajakan untuk memfokuskan siswa pada permasalahan yang dipelajari. Fenomena yang ditampilkan oleh guru untuk mengetahui kemampuan awal siswa. Setelah itu anak diminta mengidentifikasi masalah), (2) Hypothesis Generation (fenomena atau informasi yang didapatkan pada tahapan orientation digunakan pada hypothesis generation. Pada tahap ini anak menemukan jawaban atau infomasi akan membimbing anak untuk merumuskan jawaban dari masalah atau fenomena yang diberikan), (3) Hypothesis Testing (anak mencoba kegiatan, dan dalam kegiatan ini tidak dijamin kebenarannya. Apabila tidak berhasil akan di evaluasi). [10].

Serupa dengan pendapat di atas, menurut Allen mengatakan bahwa anak usia 5-6 tahun banyak menanyakan pertanyaan mengapa?, apa?, dimana?, kapan? [11]. Tujuan dari hal itu yaitu membantu anak untuk mengumpulkan informasi yang butuhkannya. Hal tersebut serupa dengan dalah satu proses berpikir kreatif yang dikemukakan Mayesky, yaitu the first part has to do with originality the discovery of an idea, plan, or answer. Tahap pertama dari proses berpikir kreatif yaitu berkaitan dengan orisinalitas dalam penemuan ide, merencanakan atau menjawab [12]. Anak yang sudah mengumpulkan informasi kemudian membuat jawaban sementara dari informasi - informasi yang didapatnya.

Anak kemudian saling bertukar informasi yang telah dimiliki agar mendapatkan jawaban dari kegiatan yang diberikan. Pada saat berbincang -bincang anak dapat mempertahankan atau merubah jawabannya. Hal itu dikarenakan pada saat anak bertukar informasi, anak akan memperoleh informasi lain yang mendukung atau sebaliknya. Pada saat berdiskusi anak belajar untuk berkomunikasi kepada orang lain. Hal tersebut serupa dengan yang diungkapkan Sherdian, bahwa "children steadily continue to develop everyday competence and power of communication" [13]. Artinya, anak semakin hari semakin mengembangkan kemampuannya dan menguatkan komunikasinya. Anak yang berbincang-bincang dengan orang lain setiap harinya akan dapat lebih mengembangkan kemampuan untuk berkomunikasi. 
Anak setelah berbincang-bincang dengan temannya, akan menyampaikan ide yang sudah dimilkinya apabila orang lain atau guru yang menanyakan terlebih dahulu. Apabila orang lain atau guru tidak bertanya, maka anak langsung mencoba ide yang dimilikinya pada kegiatan yang diberikan. Hal tersebut senada dengan beberapa tahapan proses berpikir kre atif yang diungkapkan Walas dalam Munandar, yaitu tahap verifikasi. Pada tahap ini anak akan mencoba jawaban atau ide yang dimilikinya pada kegiatan yang diberikan. [14].

Selain itu, anak setelah mencoba jawaban yang dimilikinya, anak akan mengindentifikasi apakah jawaban atau ide yang dilakukan sudah baik atau belum. Seperti yang diungkapkan Mayesky pada proses berpikir kreatif tahap kedua, yaitu the second part has to do with working out, proving, and making certain that idea or answer works or is possible [15]. Tahap kedua berpikir kreatif yaitu dengan melakukan sesuatu yaitu membuktikan, membuat gagasan atau mencari jawaban. Hal tersebut senada dengan Fisher dan Willam mengatakan proses berpikir kreatif yaitu, creative thinking is shown when children generate outcomes, show imagination and originality and can judge the value of what they have done. Proses berpikir kreatif ini terlihat saat anak menghasilkan sesuatu, menunjukkan daya imajinasi, orisinalitas, dan bisa menilai apa yang telah mereka lakukan. Pada proses berpikir kreatif tersebut anak akan diajakan untuk menemukan ide, dan mengevaluasi ide yang dimilikinya apakah sudah dapat menyelesaikan kegiatan yang diberikan atau masih membutuhkan pernyempurnaan.

\section{KESIMPULAN}

Berdasarkan temuan-temuan yang diperoleh, dapat disimpulkan bahwa metode pembelajaran discovery dalam mengembangkan proses berpikir kreatif anak di sekolah Permata Assolihin sudah cukup baik. Hal tersebut dapat dilihat dari kegiatan yang dilakukan selama pembelajaran. Kegiatan-kegiatan yang dilakukan memberikan kesempatan untuk anak mengembangkan proses berpikir kreatif. Pengembangan proses berikir kreatif dengan metode pembelajaran discovery dapat dijadikan salah satu alternatif bagi lembaga pendidikan anak usia dini.

Proses berpikir kreatif adalah kemampuan anak untuk menemukan ide-ide baru. Kemampuan ini adalah kemampuan untuk anak memecahkan suatu masalah dari sebuah kegiatan yang diberikan. Kemampuan ini tidak hanya mengembangkan kemampuan berpikir untuk menemukan ide baru, tetapi juga mengembangkan kemampuan untuk bersosialisasi, mengemukakan pendapat dan berkerja sama.

Pada metode pembelajaran discovery memiliki beberapa tahapan yaitu: Orientation (anak mendapatkan masalah dan mengumpulkan infomasi yang berkaitan dengan masalah atau kegiatan yang diberikan), Cara yang digunakan untuk mengumpulkan informasi, dapat diperoleh dengan cara bertanya dengan orang-orang sekitar yang dianggap bisa membantu untuk mengumpulkan informasi yang dibutuhkan. Mengumpulkan informasi juga dapat diperoleh dengan mengeksplorasi lingkungan sekitarnya.

Pada tahap orientation anak juga mengembangkan proses berpikir kreatif yaitu informasi yang telah dimiliki akan di diskusikan dengan teman lainnya. Melalui diskusi tersebut, anak akan saling bertukar informasi yang dimiliki untuk menemukan ide yang baru. Ide yang sudah dimiliki, akan disampaikan kepada guruntuk mengkonfirmasi ide yang dimiliki boleh dilakukan atau tidak. Apabila guru memperbolehkan mencoba ide yang dimiliki, anak akan melaksanakan ide yang dimilikinya. Tahap terakhir yaitu ide yang sudah diuji coba, kemudian akan dievaluasi bersama dengan guru,untuk mengatahui ide yang dimiliki sudah baik atau membutuhkan penyempurnaan. Selama anak berpikir kreatif untuk menemukan ide dari sebuah kegiatan yang diberikan, guru mengawasi, dan membimbing anak untuk dapat menemukan ide-ide yang baru.

Berdasarkan hasil Penelitian, terdapat beberapa saran yang dikemukakan yaitu dalam pengambilan data sebaiknya dilakukan di beberapa sekolah, sehingga dapat lebih digeneralisasikan dengan baik. Penambahan data kuantitaif pun rasanya diperlukan untuk memperdalam data yang terkait dengan variable penelitian.

\section{REFERENSI}

[1] Hanover Research, K-12 STEM Education Overview, 2011.

[2] Takdir, Pembelajaran Discovery Strategy dan Mental Vocational Skill, Jogjakarta: Diva Press, 2012.

[3] M. S. Tedjasaputra, Bermain Mainan dan Permainan, Jakarta: PT. Grasindo, 2001. 
[4] A. Anggito, Metode Penelitian Kualitatif, Sukabumi: CV Jejak, 2018.

[5] Sugiyono, Metode Penelitian Kuantitatif Kualitatif dan R\&D, Bandung: Alfabeta, 2017.

[6] L. Moleong, Metodologi Penelitian Kualitatif Edisi Revisi, Bandung: Remaja Rosdakarya, 2007.

[7] I. Gunawan, Metode Penelitian Kualitatif, Jakarta: Bumi Aksara, 2013.

[8] M. B. Miles, A. M. Huberman and J. Saldana, Qualitative Data Analysis, USA: SAGE, 2014.

[9] M. Hosnan, Pendekatan Saintifik dan Konstektual dalam pembelajaran Abad 21: Kunci sukses implementasi kurikulum, Jakarta: Rineka Cipta, 2013.

[10] I. K. d. B. Sani, Implementasi Kurikulum 2013 Konsep dan Penerapannya, Surabaya: Kata Pena, 2014.
[11] K. A. Allen, Profil Perkembangan Anak, Jakarta: Indeks, 2018.

[12] M. Mayesky, Creativve Actives and Curriculum For Young Childern, Belmont CA, USA: Cengage Learning, Inc, 2014.

[13] M. D. Sherdian's, Play In Early Childhood Fourt Edition, London: Routledge, 2017.

[14] U. Munandar, Pengembangan Kreativitas Anak Berbakat, Jakarta: Rineka Cipta, 2010.

[15] M. Mayesky, Creative Activities and Curriculum For Young Children, Belmont, CA, United States: Cengage Learning, Inc, 2014.

[16] M. S. Tedjasaputra, Bermain Mainan dan Permainan, Jakarta: PT. Grasindo, 2001. 